\title{
ALLOMETRIC GROWTH IN BRAZILIAN NATURALIZED PIGS
}

\section{CRESCIMENTO ALOMÉTRICO DE SUÍNOS BRASILEIROS NATURALIZADOS}

\author{
Bruna Dináh Krummenauer Formenton ${ }^{1}$ ORCID - http://orcid.org/0000-0001-5085-423X \\ Bruno Stefano Lima Dallago ${ }^{2}$ ORCID - http://orcid.org/0000-0003-4883-1076 \\ José Braccini Neto ${ }^{1}$ ORCID - http://orcid.org/0000-0003-2881-0235 \\ Candice Bergmann Garcia e Silva Tanure ${ }^{2}$ ORCID - http://orcid.org/0000-0002-2328-5454 \\ Vanessa Peripolli ${ }^{*}$ ORCID - http://orcid.org/0000-0002-0463-4727 \\ Concepta McManus² ORCID - http://orcid.org/0000-0002-1106-8962 \\ ${ }^{1}$ Universidade Federal do Rio Grande do Sul, Porto Alegre, RS, Brazil. \\ 2Universidade de Brasília, Brasília, DF, Brazil. \\ ${ }^{3}$ Instituto Federal Catarinense, Campus Araquari, Araquari, SC, Brazil. \\ "Corresponding author - vanessa.peripolli@hotmail.com
}

\begin{abstract}
The allometric growth of male and female naturalized pig breeds (Nilo, Piau, Moura, and Monteiro) was evaluated regarding hip height, snout length, and head length using the allometric equation. Body measurements generally show later growth in relation to the snout length and earlier growth in relation to the head length and hip height. When comparing breeds of pigs, female Moura animals showed later growth of the characteristics linked to muscle (thoracic circumference, body length, and longitudinal diameter) than of head length. Nilo females showed characteristics such as shoulder length, rump length and interschiadic distance earlier than snout length. There were differences between the breed and gender in terms of development times for the different parts of the body, showing that breeding systems and use of these animals have to be specific for each breed.
\end{abstract}

Keywords: Huxley, Monteiro, morphometrics, Moura, Nilo, Piau.

\section{Resumo}

O crescimento alométrico de raças de suínos naturalizados (Nilo, Piau, Moura e Monteiro), machos e fêmeas, foi avaliado em relação à altura do quadril, comprimento do focinho e comprimento da cabeça, usando-se a equação alométrica. As medidas do corpo geralmente apresentam um crescimento mais tardio em relação ao comprimento do focinho e precocemente em relação ao comprimento da cabeça e altura do quadril. Ao comparar as raças de suínos, as fêmeas da raça Moura apresentaram características relacionadas com o crescimento muscular (circunferência torácica, comprimento do corpo e diâmetro longitudinal) mais tardiamente ao comprimento da cabeça. Fêmeas Nilo apresentaram características do comprimento do ombro, comprimento da garupa e a distância interesquiática mais precoce em relação ao comprimento do focinho. Foram encontradas diferenças entre a raça e o sexo no tempo de desenvolvimento para as diferentes partes do corpo, mostrando que os sistemas de criação e utilização desses animais devem ser específicos para cada raça.

Palavras-chave: Huxley, Monteiro, morfometria, Moura, Nilo, Piau.

Received on: November 11th, 2015.

Accepted on: August 6th, 2018.

Cienc. anim. bras., Goiânia, v.20, 1-13, e-38449, 2019 


\section{Introduction}

Also known as Creoles, developed from breeds brought by the Portuguese and the Spanish during the sixteenth century, naturalized pig breeds in Brazil underwent hundreds of years of natural selection. These animals may have different names, but similar characteristics depending on the region where they are found, making it difficult to identify a breed standard. Similarly, little is known about the production, economic importance and geographical distribution of these animals ${ }^{(1)}$. Knowledge on the genetics, morphology, growth potential, and yield characteristics of a breed is essential to establish a rational production system ${ }^{(2)}$. Inefficiency in the forms of naturalized pig production in Brazil is visible and discrepancies in the characterization and in the name of breed groups reduces the amount and quality of information available on the genetic and functional diversity of breeds, it also creates difficulties in interpreting and organizing the few surveys performed ${ }^{(3)}$. Breed profiling is the first step towards the sustainable use of local genetic resources and data obtained from several complementary techniques are required to improve its characterization ${ }^{(4)}$ and help to emphasize the differentiation of ecotypes. Conformation is related to performance ${ }^{(5)}$, but form is only an indication of the production value of the animal.

Body measurements, along with the animal's weight, better describe an individual or population than conventional methods such as ranks and scores ${ }^{(6)}$. These measures have been found to be correlated with heat tolerance ${ }^{(7)}$, puberty and reproductive development ${ }^{(8)}$, as well as meat production ${ }^{(9)}$. They are used to define physical aspects of the environment in which animals are bred such as housing facilities, feed offer and shade requirements ${ }^{(10)}$.

These characteristics can be measured quantitatively and are, therefore, valuable tools for evaluating body growth and development, since they are related to the biological functions of animals ${ }^{(11)}$. For example, the high correlation coefficients between body weight and chest perimeter makes the estimation of body weight based on chest perimeter an efficient tool for selection of properties in animals when a weighing scale is not available, due to the high cost of this equipment ${ }^{(11)}$.

According to Santos et al. ${ }^{(12)}$, allometric studies explain quantitative differences in the different life stages of animals, being an effective manner to study their development. Allometric growth studies examine the relative growth of a body component relative to a collection of other components, identifying its rate of development ${ }^{(13)}$. Morphometric measurements performed on animals are thus important tools in the assessment of growth and body development and provide additional information that is useful for determining phenotypic and genetic trends of growth of animals over the years.

Development is a result of changes in body shape and results in the establishment of various functions for the animal such as meat production or speed of growth ${ }^{(5)}$; however, from a biological point of view, development cannot be expressed in quantitative terms. Growth, however, is associated with increased mass and body size; thus it is possible to undergo a quantitative analysis with this data. Various physiological and pathological conditions, as well as different environmental and management conditions can influence the weight of the animals, while morphometric measures tend to present fewer variations ${ }^{(14)}$.

Some measurements are more affected by muscle deposition than others. Yáñez et al. ${ }^{(15)}$ stated that some quantitative carcass traits can be predicted from biometric measurements. Chest and rump 
perimeter as well as rump width, chest width and leg perimeter in meat animals are influenced by the bone base, muscle base and fat deposits, and the adipose tissue deposition mainly in the sternum region $^{(15,16)}$. Body length, in the other hand, is based only on bone constituents. However, to the best of our knowledge, these measurements have not been taken until now for these breeds.

This study aimed to evaluate the allometric growth of various parts of four naturalized pig breeds in Brazil in relation to hip height, snout length, and head length.

\section{Material and Methods}

Two hundred and twenty male and female naturalized pigs were used. These included 63 Monteiros, 104 Mouras, 14 Nilos and 39 Piaus between 30 days and nine years of age. The traits selected as indicators of bone growth included head (HL) and snout length ( $\mathrm{SnL})$ as well as shoulder height (SH). The other traits measured included body length (BL), dorsal-sternal distance (DsD), ear length (EL), chest perimeter (CP), interschiadic distance (IqD), interorbital distance (IoD), hip length (HpL), longitudinal distance (LD), shoulder length (SL), tail length (TL), and bicostal diameter (BD) according to McManus et al. ${ }^{(1)}$ and described below (Table 1). However, not all traits were measured in all breeds due management issues.

Nilo breed was measured in the Distrito Federal state; Monteiro breed in the Pantanal region in Mato Grosso do Sul state; Moura breed in Concórdia, Santa Catarina state and Piau breed was measured in Itaberaba, Bahia state (Figure 1).

Allometric growth of the different regions was determined compared to the SH, HL and SnL using the equation defined by Huxley ${ }^{(2)}: \mathrm{Y}=\mathrm{aX}^{\mathrm{b}} \mathrm{e}$, and logarithmitised as: $\ln (\mathrm{Y})=\ln (\mathrm{a})+\mathrm{b} \ln (\mathrm{X})+$ $\ln (\mathrm{e})$. Where: "Y" is the response variable (measure of each region); "a" is the intercept; " $\mathrm{b}$ " is the allometric coefficient; " $\mathrm{X}$ " is the independent variable ( $\mathrm{SH}, \mathrm{HL}$ or $\mathrm{SnL}$ ) and " $\mathrm{e}$ " is the random error or the degree of uncertainty related to interpolation.

The hypothesis that $b=1$ was tested using the " $\mathrm{t}$ " test of Student at $5 \%$. The study was carried out by sex and breed to verify if the gender of different breeds developed differently.

Growth was considered isogonic when $b=1$, meaning that growth of each region was similar to the independent measure. When $b \neq 1$, growth of the region was precocious $(b<1)$ or late $(b>1)$ heterogonic in relation to the independent measure. Analyses were carried out using the REG procedure of SAS ${ }^{\circledR}$ v.9.3 (Statistical Analysis System, Cary, North Carolina). 
Table 1. Description and abbreviation of morphological traits measurements performed with locally adapted Brazilian pigs

\begin{tabular}{|c|c|c|}
\hline Trait & Abbreviation & Description \\
\hline $\begin{array}{l}\text { Bicostal } \\
\text { diameter }\end{array}$ & $\mathrm{BD}$ & Distance between two ribs as reference the 12 th rib \\
\hline Body length & $\mathrm{BL}$ & $\begin{array}{l}\text { Distance from the external occipital protuberance to the } \\
\text { base off the tail on the dorsal line; distance between tip of } \\
\text { scapula and ischium, measured as the distance between } \\
\text { the point of shoulder and the pin bone }\end{array}$ \\
\hline $\begin{array}{l}\text { Chest } \\
\text { perimeter }\end{array}$ & $\mathrm{CP}$ & $\begin{array}{l}\text { Total distance around the animal (circumference) } \\
\text { measured directly behind the front leg }\end{array}$ \\
\hline $\begin{array}{l}\text { Dorsal- } \\
\text { sternal } \\
\text { distance }\end{array}$ & DsD & $\begin{array}{l}\text { From the point of the shoulder to the sternum; distance } \\
\text { between back and sternum }\end{array}$ \\
\hline Ear length & EL & $\begin{array}{l}\text { From central point of the base to the vertix; from the base } \\
\text { of the notch to the most distant point of the margin of the } \\
\text { pinna (external ear) }\end{array}$ \\
\hline Head length & $\mathrm{HL}$ & $\begin{array}{l}\text { From the external occiptal protuberance to tip of nasal } \\
\text { bone }\end{array}$ \\
\hline Hip length & $\mathrm{HpL}$ & $\begin{array}{l}\text { From the external iliac tuberosity to the point of the pin } \\
\text { bone; from the external angle of the ileum to the ischiatic } \\
\text { tuberosity }\end{array}$ \\
\hline $\begin{array}{l}\text { Interischiadic } \\
\text { distance }\end{array}$ & IqD & Distance between external point of both ischial bones \\
\hline $\begin{array}{l}\text { Interorbital } \\
\text { distance }\end{array}$ & IoD & $\begin{array}{l}\text { Between both frontal sigmoid apophysis; distance } \\
\text { between left and right endocanthion }\end{array}$ \\
\hline $\begin{array}{l}\text { Longitudinal } \\
\text { distance }\end{array}$ & LD & $\begin{array}{l}\text { From the point of the shoulder to the point of the pin } \\
\text { bone }\end{array}$ \\
\hline $\begin{array}{l}\text { Shoulder } \\
\text { height }\end{array}$ & SH & $\begin{array}{l}\text { Distance from the surface of the shoulder to the point of } \\
\text { the pin bone }\end{array}$ \\
\hline $\begin{array}{l}\text { Shoulder } \\
\text { length }\end{array}$ & SL & From the superior border of the scapula to the carpus \\
\hline Snout length & $\mathrm{SnL}$ & $\begin{array}{l}\text { Tip of nasal bone to coronal suture; From the frontal- } \\
\text { nasal suture to the point of the snout }\end{array}$ \\
\hline Tail length & TL & From insertion of the tail to the tail tip \\
\hline
\end{tabular}




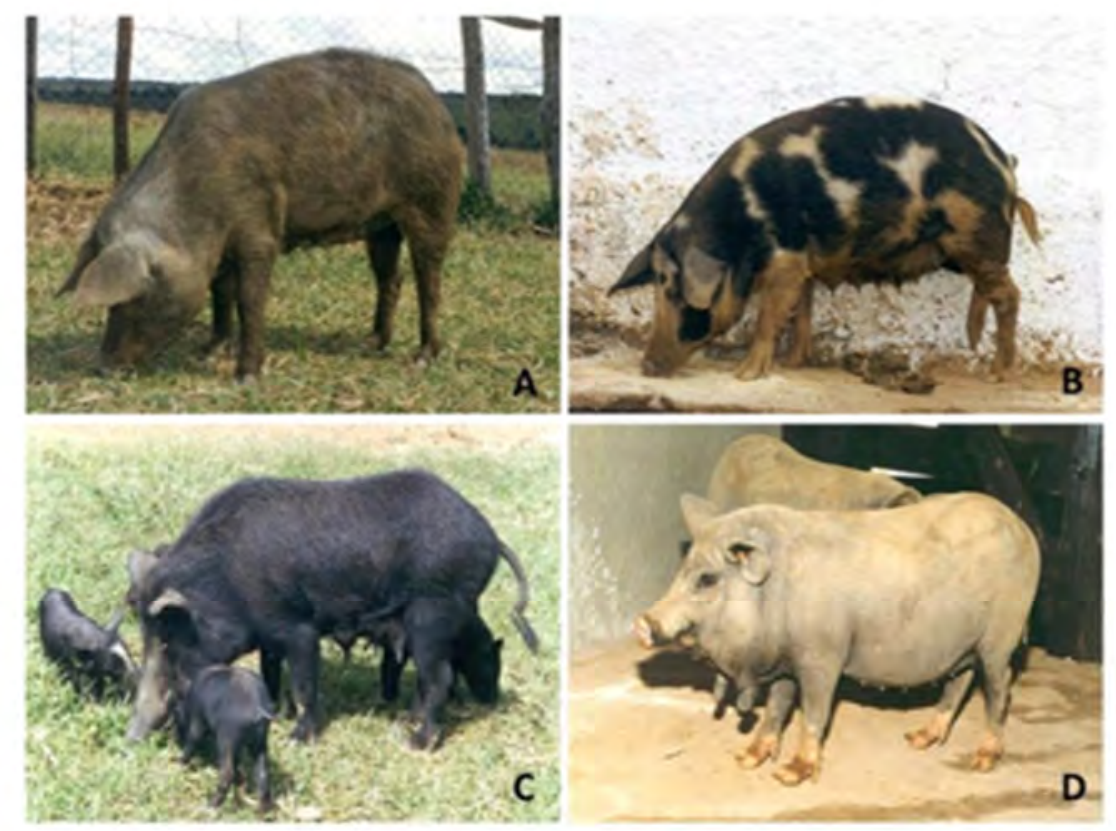

Figure 1. Brazilian naturalized pig breeds: A - Moura; B - Piau; C - Monteiro; D - Nilo.

\section{Results and Discussion}

Morphometry can help in the characterization of animal breeds as well as definition of their use. These measurements are influenced by the development of bones as well as deposition of muscle and fat $^{(15)}$. Those that are mainly linked to bone growth include head and snout length, interorbital distance, shoulder height, as well as ear, body and tail length and longitudinal distance. Other measurements are also linked to soft tissue (muscle and fat) deposition such as shoulder length, interschiadic distance, chest perimeter, dorsal-sternal distance and hip length. Changes in the proportions of animal bodies occurred with domestication as well as changes in external traits such as colour, hair type, shorter tails and droopy ears ${ }^{(17)}$.

The origin and type of rearing can explain differences in shapes of animals. Pigs were introduced into Brazil by Martim Afonso de Sousa in $1532^{(3)}$. In the beginning, these pigs were from crosses from the original Portuguese breeds (such as Alentejana and Transtagana), which arrived on the coast of São Paulo state (São Vicente city). Thenceforth many animals escaped and formed independent groups. Through crosses, several locally adapted breeds were formed such as: Canastra, Canastrão, Caruncho, Nilo, Pereira, Piau, Pirapitinga, as well as varieties such as Mule-Foot and Fish-Tail, which are practically extinct ${ }^{(18)}$. These animals belonged to the three founding trunks of pigs known today: Celtic - large late developing pig, descended from the European boar; Asian - small pigs with short ears and a tendency for fat deposition descendent from Indian pigs; and the Iberian - which is intermediate due to a remote hybridization of the other two trunks (Table 2)

The Nilo is a small hairless Asian type pig similar to the Alentejano from Portugal and the Iberian from Spain which fatten easily ${ }^{(3)}$. The Piau was the first locally adapted breed to be registered in the Brazilian Pig Book and it is thought to have originated from crosses between the Canastra, with 
Poland China and Duroc, thereby being a more meat type animal ${ }^{(3)}$. The Monteiro can be found in the Brazilian Pantanal region and originated from farm animals (Duroc, Tamworth and Caruncho) that escaped or were abandoned during the Paraguay war (1864-1870) and survived in the wild ${ }^{(3)}$. Moura is reared in the South of the country being housed in the winter and fattened at pasture during the spring and summer ${ }^{(3)}$.

Table 2. Breed traits of locally adapted Brazilian pigs

\begin{tabular}{|c|c|c|c|c|}
\hline Breed & Origin & Hair type & Ear type $^{1}$ & Head shape ${ }^{2}$ \\
\hline Moura & $\begin{array}{l}\text { Crosses between } \\
\text { Canastra and Duroc or } \\
\text { between Canastra, } \\
\text { Canastrão and } \\
\text { Yorkshire }\end{array}$ & $\begin{array}{l}\text { Dapple grey; sometimes } \\
\text { pink. Mixed black and } \\
\text { white hair, distributed } \\
\text { uniformly throughout the } \\
\text { body }\end{array}$ & $\mathrm{I}$ to $\mathrm{C}$ & $\mathrm{R}$ and $\mathrm{S}$ \\
\hline Piau & $\begin{array}{c}\text { Crosses between Poland } \\
\text { China, Duroc, Canastra } \\
\text { and Canastrão }\end{array}$ & $\begin{array}{l}\text { White and cream with } \\
\text { black spots. Tricolour } \\
\text { (White, black and red) are } \\
\text { tolerated }\end{array}$ & $\mathrm{I}^{3}$ to $\mathrm{C}^{4}$ & $\mathrm{R}$ to $\mathrm{S}$ \\
\hline Monteiro & Wild Pigs & $\begin{array}{l}\text { One colour, generally } \\
\text { black or dark brown, no } \\
\text { spots or markings }\end{array}$ & I & $\mathrm{R}$ \\
\hline Nilo & $\begin{array}{c}\text { Obscure } \\
\text { Canastra x Tatu }{ }^{5,6}\end{array}$ & $\begin{array}{l}\text { Black, generally hairless, } \\
\text { sometimes with white } \\
\text { marks on the body and } \\
\text { extremities (undesirable). } \\
\text { Hairs, when present, are } \\
\text { few and fine }\end{array}$ & I & $\mathrm{S}$ to $\mathrm{R}$ \\
\hline
\end{tabular}

${ }^{1} \mathrm{I}$ - Iberian; C - Celtic; ${ }^{2} \mathrm{R}$ - Rectilinear; S - Subconvex; ${ }^{3}$ These were found in São Carlos; ${ }^{4}$ These were found in Uberaba; ${ }^{5}$ Similar to the hairless breed Teano, sub-breed Napolitana; ${ }^{6}$ It is believed that this cross created Nilo breed.

The development of body traits in general (Table 3) is later than the development of snout length $(b>1)$, but earlier than the development of head length and hip height (both with $b<1$ ). Additionally, the mean to body traits for allometric growth in relation to $\mathrm{SnL}(\mathrm{b}$ mean $=1.70)$ was different $(P<0.0001)$ to body traits means in relation to HH (b mean $=0.56)$ and HL (b mean $=0.47)$. Snout length was the earliest developing traits and body length was the latest. An animal is born with a large snout compared to body and head proportions. This may be related to a smaller body area in young animals to avoid heat loss and a large snout is important for contact with the dam and feeding. Different from other domestic animals, the pig uses its snout to look for food ${ }^{(18)}$ and even dig. McManus et al. ${ }^{(1)}$ stated that head traits are strongly related to breed while body traits are strongly influenced by the environment, depending on feeding regime and rearing system. 
Table 3. Coefficients of allometry (b) and determination $\left(R^{2}\right)$ for linear body measurements in relation to hip height, snout and head length in locally adapted Brazilian pig breeds

\begin{tabular}{|c|c|c|c|c|c|c|c|c|c|c|c|c|}
\hline & \multicolumn{4}{|c|}{ Hip Height (HH) } & \multicolumn{4}{|c|}{ Snout Length (SnL) } & \multicolumn{4}{|c|}{ Head Length (HL) } \\
\hline & $\ln (\mathbf{a})$ & error & $\mathbf{R}^{2}$ & b & $\ln (\mathbf{a})$ & error & $\mathbf{R}^{2}$ & b & $\ln (\mathbf{a})$ & error & $\mathbf{R}^{2}$ & b \\
\hline $\mathrm{HH}$ & - & - & - & - & 0.77 & 0.03 & 0.79 & 2.21 & 1.03 & 0.03 & 0.84 & 0.63 \\
\hline $\mathrm{SnL}$ & 1.03 & 0.03 & 0.79 & 1.82 & - & - & - & - & 1.16 & 0.04 & 0.79 & 1.47 \\
\hline $\mathrm{HL}$ & 0.81 & 0.02 & 0.8 & 0.00 & 0.68 & 0.02 & 0.79 & 1.67 & - & 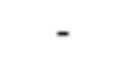 & - & \\
\hline IoD & 0.48 & 0.02 & 0.68 & 0.2 & 0.39 & 0.02 & 0.57 & 1.27 & 0.57 & & & 0.32 \\
\hline EL & 0.73 & 0.02 & 0.73 & 0.26 & 0.59 & 0.03 & 0.64 & 1.28 & 0.79 & 0.03 & 0.69 & 0.07 \\
\hline TL & 0.88 & 0.05 & 0.65 & 0.57 & 0.67 & 0.05 & 0.56 & 1.39 & 0.99 & 0.07 & 0.64 & 0.31 \\
\hline $\mathrm{CP}$ & 0.99 & 0.02 & 0.86 & 0.44 & 0.80 & 0.03 & 0.74 & 2.55 & 1.09 & 0.03 & 0.81 & 0.86 \\
\hline $\mathrm{BL}$ & 0.93 & 0.05 & 0.59 & 0.6 & 0.75 & 0.05 & 0.50 & 2.61 & 1.01 & 0.06 & 0.53 & 1.06 \\
\hline LD & 0.80 & 0.07 & 0.37 & 0.78 & 0.62 & 0.07 & 0.29 & 2.60 & 0.84 & 0.09 & 0.33 & 1.30 \\
\hline DeD & 1.06 & 0.02 & 0.91 & 0.53 & 0.79 & 0.04 & 0.71 & 1.91 & 1.20 & 0.04 & 0.86 & 0.14 \\
\hline $\mathrm{BD}$ & 0.81 & 0.24 & 0.11 & 0.80 & 0.55 & 0.18 & 0.09 & 1.15 & 0.83 & 0.24 & 0.11 & 0.28 \\
\hline SL & 0.93 & 0.04 & 0.64 & 0.63 & 0.74 & 0.05 & 0.53 & 1.37 & 0.95 & 0.06 & 0.51 & 0.00 \\
\hline $\mathrm{HpL}$ & 0.87 & 0.07 & 0.38 & 0.34 & 0.69 & 0.07 & 0.30 & 1.53 & 0.93 & 0.09 & 0.33 & 0.07 \\
\hline IqD & 0.98 & 0.03 & 0.80 & 1.03 & 0.77 & 0.04 & 0.71 & 1.10 & 1.13 & 0.04 & 0.79 & 0.78 \\
\hline
\end{tabular}

HH=Hip Height; SnL=Snout Length; HL=Head Length; IoD=Interorbital distance; EL=Ear Length; $\mathrm{TL}=$ Tail Length; $\mathrm{CP}=$ Chest perimeter; $\mathrm{BL}=$ Body length $\mathrm{LD}=$ Longitudinal Diameter; $\mathrm{DsD}=\mathrm{Dorsal}$-sternal Diameter; $\mathrm{BD}=\mathrm{Bicostal}$ Diameter; $\mathrm{SL}=$ Shoulder Length; $\mathrm{HpL}=$ Hip Length; IqD=Interischiadic Distance.

Moura females, compared to Piau and Monteiro (Table 4), presented later muscle development compared to head length (i.e. Chest perimeter, Body Length and Longitudinal Distance developed later). The latter two breeds had previously been selected for early muscle development ${ }^{(19)}$. Females are usually physiologically more mature at earlier ages than males and fat proportion is also greater in females at earlier ages ${ }^{(20)}$.

The coefficients of determination were generally high while the allometric coefficients between animals of different gender were of the same magnitude, but differed between breeds as breeds show different development patterns. This fact should be taken into account when developing management and breeding plans for these animals (Tables 4, 5 and 6). Allometric growth (the proportionality with which animal develop) can help in the selection of the best biotype for a certain environment, interfering directly on the quality of its carcass. As there are growth phases when certain parts of the body develop earlier and as here exists first and second quality cuts, it is important to identify when the best carcass proportions can be obtained, especially for the more expensive cuts. According to Lui and Baron ${ }^{(21)}$, the speed of development of a certain body region advances until it reaches a maximum and then starts to decrease as the animal reaches adulthood. According to Almeida ${ }^{(22)}$, the growth curves of carcass components (muscle, fat and bone) in fattening animals showed that muscle and bone tissue grow proportionally slower than the whole carcass while the opposite happens with fat; thus, the animal gets fatter as it ages. 
Table 4. Coefficients of allometry (b) and determination $\left(R^{2}\right)$ for linear body measurements in relation to head length in locally adapted Brazilian pig breeds

\begin{tabular}{|c|c|c|c|c|c|c|c|c|}
\hline & \multicolumn{4}{|c|}{ Female } & \multicolumn{4}{|c|}{ Male } \\
\hline & $\ln (\mathbf{a})$ & error & $\mathbf{R}^{2}$ & $\mathbf{b}$ & $\ln (\mathbf{a})$ & error & $\mathbf{R}^{2}$ & b \\
\hline & \multicolumn{8}{|c|}{ Moura } \\
\hline $\mathrm{HH}$ & 1.09 & 0.04 & 0.93 & 0.49 & 1.08 & 0.04 & 0.95 & 0.50 \\
\hline $\mathrm{SnL}$ & 1.16 & 0.04 & 0.92 & 1.49 & 1.06 & 0.06 & 0.88 & 1.15 \\
\hline IoD & 0.65 & 0.04 & 0.83 & 0.08 & 0.65 & 0.05 & 0.83 & 0.11 \\
\hline $\mathrm{EL}$ & 0.76 & 0.04 & 0.84 & 0.31 & 0.89 & 0.04 & 0.91 & 0.10 \\
\hline $\mathrm{TL}$ & 1.21 & - & 1.00 & 0.87 & - & - & - & - \\
\hline $\mathrm{CP}$ & 1.20 & 0.04 & 0.92 & 0.66 & 1.10 & 0.04 & 0.95 & 0.92 \\
\hline $\mathrm{BL}$ & 1.21 & 0.04 & 0.94 & 0.69 & 1.10 & 0.04 & 0.94 & 0.99 \\
\hline $\mathrm{LD}$ & 1.10 & 0.04 & 0.92 & 0.74 & 1.04 & 0.06 & 0.89 & 0.93 \\
\hline DsD & 1.24 & 0.05 & 0.92 & 0.18 & 1.16 & 0.05 & 0.93 & 0.01 \\
\hline SL & 0.99 & 0.08 & 0.70 & 0.06 & 0.79 & 0.08 & 0.71 & 0.65 \\
\hline $\mathrm{HpL}$ & 1.04 & 0.07 & 0.78 & 0.11 & 1.03 & 0.07 & 0.85 & 0.09 \\
\hline \multirow[t]{2}{*}{ IqQD } & 0.81 & 0.07 & 0.66 & 0.25 & 0.89 & 0.06 & 0.83 & 0.01 \\
\hline & \multicolumn{8}{|c|}{ Piau } \\
\hline $\mathrm{HH}$ & 1.19 & 0.08 & 0.92 & 0.08 & 1.08 & 0.08 & 0.93 & 0.39 \\
\hline $\mathrm{SnL}$ & 1.57 & 0.38 & 0.45 & 2.83 & 1.31 & 0.07 & 0.96 & 2.02 \\
\hline IoD & 0.43 & 0.13 & 0.36 & 0.80 & 0.64 & 0.05 & 0.92 & 0.10 \\
\hline $\mathrm{EL}$ & 1.01 & 0.09 & 0.85 & 0.80 & 1.00 & 0.08 & 0.92 & 0.70 \\
\hline $\mathrm{TL}$ & 1.09 & 0.08 & 0.90 & 0.55 & 1.29 & 0.09 & 0.94 & 1.17 \\
\hline $\mathrm{CP}$ & 1.47 & 0.11 & 0.90 & 0.47 & 1.26 & 0.06 & 0.97 & 0.15 \\
\hline BL & 1.30 & 0.07 & 0.94 & 0.23 & 1.20 & 0.12 & 0.87 & 0.42 \\
\hline LD & 1.22 & 0.07 & 0.94 & 0.23 & 1.07 & 0.10 & 0.90 & 0.67 \\
\hline DsD & 1.37 & 0.09 & 0.93 & 0.84 & 0.93 & 0.12 & 0.81 & 0.39 \\
\hline BD & 1.04 & 0.12 & 0.79 & 2.05 & 0.89 & 0.10 & 0.89 & 1.53 \\
\hline SL & 0.94 & 0.17 & 0.60 & 0.12 & 0.70 & 0.13 & 0.66 & 0.77 \\
\hline $\mathrm{HpL}$ & 1.49 & 0.07 & 0.96 & 1.60 & 1.32 & 0.10 & 0.93 & 1.08 \\
\hline \multirow[t]{2}{*}{ IqQD } & 1.65 & 0.11 & 0.92 & 2.53 & 1.26 & 0.10 & 0.92 & 1.33 \\
\hline & \multicolumn{8}{|c|}{ Monteiro } \\
\hline $\mathrm{HH}$ & 0.88 & 0.14 & 0.58 & 1.12 & 0.68 & 0.14 & 0.58 & 1.79 \\
\hline $\mathrm{SnL}$ & 0.97 & 0.09 & 0.77 & 0.87 & 0.80 & 0.10 & 0.74 & 0.31 \\
\hline IoD & 0.46 & 0.07 & 0.58 & 0.58 & 0.51 & 0.07 & 0.68 & 0.47 \\
\hline $\mathrm{EL}$ & 0.96 & 0.08 & 0.79 & 0.58 & 0.46 & 0.11 & 0.45 & 1.02 \\
\hline$\overline{T L}$ & 1.14 & 0.09 & 0.83 & 0.79 & 0.64 & 0.13 & 0.59 & 0.82 \\
\hline $\mathrm{CP}$ & 1.12 & 0.10 & 0.79 & 0.60 & 0.84 & 0.11 & 0.73 & 1.54 \\
\hline BL & 1.06 & 0.09 & 0.80 & 0.41 & 0.80 & 0.11 & 0.70 & 1.29 \\
\hline LD & 1.11 & 0.18 & 0.55 & 0.21 & 0.74 & 0.12 & 0.67 & 1.05 \\
\hline $\mathrm{BD}$ & 1.17 & 0.17 & 0.58 & 0.88 & 0.76 & 0.19 & 0.40 & 0.50 \\
\hline $\mathrm{SL}$ & 1.16 & 0.12 & 0.74 & 0.81 & 0.88 & 0.13 & 0.65 & 0.16 \\
\hline \multirow[t]{2}{*}{$\mathrm{HpL}$} & 0.86 & 0.13 & 0.56 & 0.41 & 0.89 & 0.15 & 0.62 & 0.43 \\
\hline & \multicolumn{8}{|c|}{ Nilo } \\
\hline $\mathrm{HH}$ & 0.97 & 0.11 & 0.97 & 0.62 & 1.26 & 0.14 & 0.92 & 0.21 \\
\hline $\mathrm{SnL}$ & 1.34 & 0.04 & 1.00 & 2.08 & 1.32 & 0.14 & 0.93 & 2.17 \\
\hline IoD & 0.76 & 0.02 & 1.00 & 0.24 & 0.66 & 0.13 & 0.80 & 0.08 \\
\hline EL & 0.94 & 0.07 & 0.98 & 0.57 & 0.99 & 0.11 & 0.95 & 0.72 \\
\hline TL & 0.18 & 0.27 & 0.18 & 1.63 & 0.76 & 0.25 & 0.61 & 0.20 \\
\hline $\mathrm{CP}$ & 1.24 & 0.09 & 0.99 & 0.35 & 1.32 & 0.16 & 0.90 & 0.19 \\
\hline BL & 1.30 & 0.07 & 0.99 & 0.21 & 1.25 & 0.10 & 0.96 & 0.30 \\
\hline $\mathrm{SL}$ & 1.09 & 0.16 & 0.94 & 1.14 & 1.17 & 0.11 & 0.94 & 1.28 \\
\hline $\mathrm{HpL}$ & 1.24 & 0.09 & 0.98 & 0.96 & 1.21 & 0.11 & 0.95 & 0.89 \\
\hline IqD & 1.26 & 0.26 & 0.88 & 1.39 & 1.57 & 0.18 & 0.92 & 2.17 \\
\hline
\end{tabular}


Table 5. Differences between coefficients of allometry (b) in relation to snout length in locally adapted Brazilian pig breeds by gender and breed

\begin{tabular}{|c|c|c|c|c|}
\hline \multirow{2}{*}{ Breed } & \multicolumn{2}{|c|}{ Female } & \multicolumn{2}{|c|}{ Male } \\
\hline & Mean & SD & Mean & SD \\
\hline Moura & $1.63^{b}$ & 0.48 & $1.80^{\mathrm{ab}}$ & 0.79 \\
\hline Piau & $2.60^{\mathrm{a}}$ & 0.80 & $1.44^{b}$ & 0.71 \\
\hline Monteiro & $1.07^{b}$ & 0.57 & $1.25^{\mathrm{b}}$ & 0.58 \\
\hline Nilo & $1.40^{\mathrm{b}}$ & 0.69 & $1.44^{b}$ & 0.66 \\
\hline
\end{tabular}

SD-standard deviation; Different letters $(\mathrm{a}, \mathrm{b})$ means significant difference by Tukey test $(5 \%)$.

Table 6. Coefficients of allometry (b) and determination $\left(\mathrm{R}^{2}\right)$ for linear body measurements in relation to snout length in locally adapted Brazilian pig breeds

\begin{tabular}{|c|c|c|c|c|c|c|c|c|}
\hline & \multicolumn{4}{|c|}{ Female } & \multicolumn{4}{|c|}{ Male } \\
\hline & $\ln (\mathbf{a})$ & error & $\mathbf{R}^{2}$ & b & $\ln (a)$ & error & $\mathbf{R}^{2}$ & b \\
\hline \multicolumn{9}{|c|}{ Moura } \\
\hline $\mathrm{HH}$ & 0.89 & 0.04 & 0.89 & 2.01 & 0.91 & 0.06 & 0.87 & 1.88 \\
\hline IoD & 0.54 & 0.03 & 0.81 & 0.97 & 0.54 & 0.05 & 0.74 & 0.96 \\
\hline EL & 0.62 & 0.04 & 0.82 & 1.34 & 0.74 & 0.06 & 0.82 & 1.06 \\
\hline TL & 0.87 & - & 1.00 & 1.07 & - & - & - & 3.78 \\
\hline $\mathrm{CP}$ & 0.97 & 0.04 & 0.89 & 2.31 & 0.93 & 0.06 & 0.87 & 2.33 \\
\hline $\mathrm{BL}$ & 0.99 & 0.04 & 0.91 & 2.37 & 0.94 & 0.05 & 0.89 & 2.37 \\
\hline LD & 0.90 & 0.04 & 0.88 & 2.26 & 0.88 & 0.07 & 0.81 & 2.25 \\
\hline DsD & 1.02 & 0.04 & 0.91 & 1.49 & 0.98 & 0.07 & 0.84 & 1.50 \\
\hline $\mathrm{SL}$ & 0.80 & 0.07 & 0.67 & 1.44 & 0.72 & 0.07 & 0.75 & 1.56 \\
\hline $\mathrm{HpL}$ & 0.84 & 0.06 & 0.74 & 1.57 & 0.84 & 0.08 & 0.72 & 1.48 \\
\hline \multirow[t]{2}{*}{ IqD } & 0.65 & 0.06 & 0.63 & 1.37 & 0.77 & 0.06 & 0.79 & 1.11 \\
\hline & \multicolumn{8}{|c|}{ Piau } \\
\hline $\mathrm{HH}$ & 0.33 & 0.09 & 0.40 & 3.30 & 0.83 & 0.04 & 0.98 & 2.05 \\
\hline IoD & 0.01 & 0.07 & 0.00 & 2.25 & 0.48 & 0.03 & 0.93 & 1.09 \\
\hline EL & 0.28 & 0.08 & 0.37 & 1.95 & 0.73 & 0.07 & 0.87 & 0.89 \\
\hline TL & 0.28 & 0.09 & 0.33 & 2.45 & 0.98 & 0.04 & 0.98 & 0.83 \\
\hline $\mathrm{CP}$ & 0.44 & 0.11 & 0.43 & 3.45 & 0.94 & 0.05 & 0.97 & 2.13 \\
\hline $\mathrm{BL}$ & 0.38 & 0.09 & 0.46 & 3.69 & 0.91 & 0.08 & 0.90 & 2.27 \\
\hline $\mathrm{LD}$ & 0.35 & 0.09 & 0.43 & 3.47 & 0.79 & 0.06 & 0.93 & 2.35 \\
\hline DsD & 0.39 & 0.11 & 0.41 & 2.86 & 0.69 & 0.08 & 0.84 & 1.85 \\
\hline $\mathrm{BD}$ & 0.32 & 0.09 & 0.41 & 0.70 & 0.69 & 0.08 & 0.90 & 0.19 \\
\hline $\mathrm{SL}$ & 0.31 & 0.09 & 0.36 & 2.53 & 0.52 & 0.10 & 0.66 & 1.87 \\
\hline $\mathrm{HpL}$ & 0.40 & 0.11 & 0.38 & 2.48 & 1.01 & 0.05 & 0.96 & 0.95 \\
\hline \multirow[t]{2}{*}{ IqD } & 0.45 & 0.13 & 0.37 & 1.97 & 0.94 & 0.08 & 0.91 & 0.65 \\
\hline & \multicolumn{8}{|c|}{ Monteiro } \\
\hline $\mathrm{HH}$ & 0.91 & 0.11 & 0.70 & 1.90 & 0.86 & 0.09 & 0.83 & 2.01 \\
\hline IoD & 0.41 & 0.06 & 0.56 & 1.14 & 0.59 & 0.06 & 0.79 & 0.78 \\
\hline EL & 0.89 & 0.07 & 0.84 & 0.51 & 0.48 & 0.12 & 0.43 & 1.40 \\
\hline TL & 1.03 & 0.08 & 0.82 & 0.58 & 0.71 & 0.14 & 0.58 & 1.24 \\
\hline $\mathrm{CP}$ & 1.03 & 0.08 & 0.81 & 1.90 & 0.96 & 0.09 & 0.84 & 2.05 \\
\hline BL & 0.95 & 0.08 & 0.79 & 1.68 & 0.92 & 0.09 & 0.84 & 1.74 \\
\hline LD & 1.08 & 0.16 & 0.59 & 0.95 & 0.81 & 0.12 & 0.71 & 1.57 \\
\hline DsD & 1.07 & 0.15 & 0.59 & 0.50 & 0.92 & 0.18 & 0.52 & 0.84 \\
\hline SL & 1.09 & 0.10 & 0.78 & 0.50 & 0.98 & 0.13 & 0.71 & 0.76 \\
\hline \multirow[t]{2}{*}{$\mathrm{HpL}$} & 0.76 & 0.12 & 0.52 & 0.68 & 0.98 & 0.15 & 0.67 & 0.19 \\
\hline & \multicolumn{8}{|c|}{ Nilo } \\
\hline $\mathrm{HH}$ & 0.72 & 0.09 & 0.96 & 2.13 & 0.91 & 0.11 & 0.91 & 1.92 \\
\hline $\mathrm{HL}$ & 0.74 & 0.02 & 1.00 & 1.55 & 0.70 & 0.08 & 0.93 & 1.73 \\
\hline IoD & 0.56 & 0.03 & 0.99 & 0.95 & 0.50 & 0.08 & 0.86 & 1.17 \\
\hline EL & 0.69 & 0.06 & 0.98 & 0.89 & 0.72 & 0.15 & 0.82 & 0.94 \\
\hline TL & 0.12 & 0.21 & 0.14 & 1.94 & 0.55 & 0.17 & 0.64 & 1.51 \\
\hline $\mathrm{CP}$ & 0.92 & 0.07 & 0.98 & 2.28 & 0.97 & 0.10 & 0.93 & 2.39 \\
\hline BL & 0.96 & 0.06 & 0.99 & 2.22 & 0.92 & 0.06 & 0.97 & 2.40 \\
\hline $\mathrm{SL}$ & 0.80 & 0.13 & 0.93 & 0.57 & 0.85 & 0.09 & 0.92 & 0.70 \\
\hline $\mathrm{HpL}$ & 0.91 & 0.10 & 0.97 & 0.97 & 0.88 & 0.09 & 0.93 & 1.18 \\
\hline IqD & 0.94 & 0.20 & 0.88 & 0.56 & 1.14 & 0.13 & 0.91 & 0.48 \\
\hline
\end{tabular}

Growth curves differ by breed, gender, and individual, where large framed animals (heavier at 
maturity) accumulate fat at heavier weights. Animals that have higher mature size are less mature than those of low mature size, if compared at the same weight during growth and tend to have deposited less fat. According to Ávila and Osório ${ }^{(23)}$, allometry is based on the fact that body development is weight related and not based on the time needed to reach that weight. In the present study, weights were not available so other body parts were used for comparison.

Breeds differ in body size due to their origin and the manner in which they are reared. The Moura breed tends to develop HpL earlier than the other breeds $(b<1)$ and tends to develop BL later compared to HL (Table 4). Its body development shows a wide back and loin as well as a short neck ${ }^{(3)}$. The Piau breed is closest to the commercial breeds in terms of development, especially in comparison with the Monteiro breed ${ }^{(3)}$.

In general, other body parts of Monteiro (male and female), Nilo (male and female) and Moura (female) pigs grow faster in relation to $\operatorname{SnL}(P=0.0013)$. Piau female and Moura male did not present difference in allometric growth in relation to $\mathrm{SnL}$ (Table 5). Nilo females showed more precocious $\mathrm{SL}, \mathrm{HpL}$ and IqD in relation to SnL, compared to Piau and Moura (Table 6). This may be due to the fact that it is a lard type pig, which needs less bone growth for fat deposition.

The Monteiro is considered a wild pig, similar to the boar. It has a cone shaped head and a long snout $^{(3)}$. Its females show body growth proportional to hip height (b value close to 1 ). This faster growth may be due to its need to look for food as well as escape from predators. The males have an earlier development of $\mathrm{BL}$ and $\mathrm{LD}$ than $\mathrm{HH}$, compared to the other breeds, thereby maintaining a similar body profile throughout its development (Table 7). In relation to $\mathrm{HH}$, there was a difference in allometric growth between Moura and Nilo breeds and no difference between Piau, Monteiro and between this breed and Moura and Nilo breeds (Table 8).

Traits linked to soft tissue and bone develop at different rates, therefore their relative growth, depends on the traits selected. This explains why those relative to HL and SH are different. The Moura, Piau and Nilo breeds tend to develop earlier for the SH (Table 4) compared to HL, in both males and females.

Dutra Jr. et al. ${ }^{(24)}$ studied extended allometric curves in commercial pigs and determined that from 50 to $120 \mathrm{~kg}$ pigs deposit, in proportional terms, increasing amounts of muscle and fat, while bone proportion remains relatively unaltered and skin proportions reduces slightly. As the animal ages, fat deposition becomes more pronounced than muscle.

As in the present study, growth differed between breeds and gender. Management systems for these should take this into consideration to produce animals suitable for prevailing market conditions. For example, when rearing Moura pigs, the farmer must be prepared to obtain carcass with more meat in later times. The facilities and husbandry must consider the body characteristics as earlier development of longitudinal distance in Monteiro male pigs, providing them with sufficient space and care. In addition, breeding programs need body growth data as well as production data to support their databank and subsidies breeding decisions. 
Table 7. Coefficients of allometry (b) and determination $\left(R^{2}\right)$ for linear body measurements in relation to hip height in locally adapted Brazilian pig breeds

\begin{tabular}{|c|c|c|c|c|c|c|c|c|}
\hline & \multicolumn{4}{|c|}{ Female } & \multicolumn{4}{|c|}{ Male } \\
\hline & $\ln (a)$ & error & $\mathbf{R}^{2}$ & b & $\ln (a)$ & error & $\mathbf{R}^{2}$ & b \\
\hline & \multicolumn{8}{|c|}{ Moura } \\
\hline $\mathrm{SnL}$ & 0.85 & 0.03 & 0.93 & 0.20 & 0.88 & 0.03 & 0.95 & 0.28 \\
\hline IoD & 0.55 & 0.04 & 0.76 & 0.04 & 0.57 & 0.05 & 0.80 & 0.09 \\
\hline $\mathrm{EL}$ & 0.68 & 0.03 & 0.87 & 0.02 & 0.78 & 0.05 & 0.87 & 0.36 \\
\hline TL & 1.19 & - & 1.00 & 1.51 & - & - & - & - \\
\hline $\mathrm{CP}$ & 1.08 & 0.03 & 0.97 & 0.18 & 1.00 & 0.03 & 0.97 & 0.48 \\
\hline $\mathrm{BL}$ & 1.09 & 0.03 & 0.97 & 0.25 & 1.00 & 0.04 & 0.95 & 0.57 \\
\hline LD & 0.98 & 0.03 & 0.94 & 0.36 & 0.93 & 0.04 & 0.92 & 0.56 \\
\hline DsD & 1.10 & 0.03 & 0.95 & 0.63 & 1.02 & 0.04 & 0.93 & 0.34 \\
\hline SL & 0.90 & 0.07 & 0.75 & 0.36 & 0.73 & 0.07 & 0.73 & 0.30 \\
\hline $\mathrm{HpL}$ & 0.97 & 0.05 & 0.88 & 0.44 & 0.95 & 0.06 & 0.88 & 0.35 \\
\hline \multirow[t]{2}{*}{ IqD } & 0.74 & 0.06 & 0.71 & 0.12 & 0.80 & 0.06 & 0.82 & 0.32 \\
\hline & \multicolumn{8}{|c|}{ Piau } \\
\hline $\mathrm{SnL}$ & 0.77 & 0.05 & 0.92 & 0.23 & 0.86 & 0.06 & 0.93 & 0.14 \\
\hline IoD & 0.37 & 0.10 & 0.40 & 0.74 & 0.56 & 0.05 & 0.90 & 0.04 \\
\hline EL & 0.80 & 0.08 & 0.81 & 0.64 & 0.85 & 0.10 & 0.83 & 0.79 \\
\hline TL & 0.86 & 0.07 & 0.87 & 0.41 & 1.18 & 0.05 & 0.98 & 1.57 \\
\hline $\mathrm{CP}$ & 1.21 & 0.07 & 0.94 & 0.45 & 1.12 & 0.06 & 0.96 & 0.13 \\
\hline BL & 1.05 & 0.05 & 0.95 & 0.33 & 1.10 & 0.09 & 0.91 & 0.03 \\
\hline LD & 0.96 & 0.07 & 0.90 & 0.37 & 0.92 & 0.06 & 0.95 & 0.52 \\
\hline DsD & 1.12 & 0.07 & 0.94 & 0.79 & 0.78 & 0.10 & 0.81 & 0.33 \\
\hline $\mathrm{BD}$ & 0.84 & 0.10 & 0.78 & 1.97 & 0.83 & 0.07 & 0.93 & 1.90 \\
\hline SL & 0.81 & 0.12 & 0.70 & 0.06 & 0.66 & 0.10 & 0.74 & 0.46 \\
\hline $\mathrm{HpL}$ & 1.19 & 0.07 & 0.94 & 1.43 & 1.18 & 0.08 & 0.93 & 1.42 \\
\hline \multirow[t]{2}{*}{ IqD } & 1.32 & 0.09 & 0.91 & 2.37 & 1.10 & 0.11 & 0.88 & 1.55 \\
\hline & \multicolumn{8}{|c|}{ Monteiro } \\
\hline SnL & 0.65 & 0.10 & 0.58 & 0.68 & 0.86 & 0.17 & 0.58 & 0.23 \\
\hline IoD & 0.37 & 0.06 & 0.51 & 0.60 & 0.57 & 0.08 & 0.74 & 0.16 \\
\hline $\mathrm{EL}$ & 0.78 & 0.09 & 0.69 & 0.52 & 0.44 & 0.14 & 0.35 & 0.77 \\
\hline TL & 0.97 & 0.09 & 0.78 & 0.92 & 0.62 & 0.17 & 0.51 & 0.34 \\
\hline $\mathrm{CP}$ & 0.91 & 0.10 & 0.73 & 0.67 & 0.96 & 0.11 & 0.82 & 0.45 \\
\hline $\mathrm{BL}$ & 0.84 & 0.11 & 0.66 & 0.53 & 0.99 & 0.10 & 0.85 & 0.06 \\
\hline LD & 0.96 & 0.16 & 0.55 & 0.38 & 0.87 & 0.12 & 0.74 & 0.06 \\
\hline $\mathrm{BD}$ & 0.75 & 0.12 & 0.54 & 0.08 & 0.97 & 0.07 & 0.92 & 0.78 \\
\hline SL & 0.90 & 0.13 & 0.62 & 0.56 & 1.09 & 0.10 & 0.87 & 1.30 \\
\hline \multirow[t]{2}{*}{$\mathrm{HpL}$} & 0.60 & 0.12 & 0.45 & 0.03 & 1.11 & 0.12 & 0.82 & 1.97 \\
\hline & \multicolumn{8}{|c|}{ Nilo } \\
\hline HL & 0.99 & 0.11 & 0.97 & 0.52 & 0.73 & 0.08 & 0.92 & 0.38 \\
\hline IoD & 0.76 & 0.08 & 0.97 & 0.63 & 0.51 & 0.09 & 0.83 & 0.22 \\
\hline $\mathrm{EL}$ & 0.95 & 0.03 & 1.00 & 1.12 & 0.75 & 0.15 & 0.83 & 0.43 \\
\hline TL & 0.18 & 0.24 & 0.21 & 1.54 & 0.64 & 0.14 & 0.79 & 0.22 \\
\hline $\mathrm{CP}$ & 1.23 & 0.15 & 0.96 & 0.30 & 1.03 & 0.09 & 0.95 & 0.47 \\
\hline $\mathrm{BL}$ & 1.30 & 0.10 & 0.98 & 0.51 & 0.94 & 0.10 & 0.93 & 0.70 \\
\hline SL & 1.12 & 0.12 & 0.96 & 1.81 & 0.90 & 0.07 & 0.96 & 1.00 \\
\hline $\mathrm{HpL}$ & 1.24 & 0.11 & 0.98 & 1.65 & 0.90 & 0.11 & 0.91 & 0.49 \\
\hline IqD & 1.25 & 0.31 & 0.85 & 2.03 & 1.16 & 0.17 & 0.87 & 1.64 \\
\hline
\end{tabular}

$\mathrm{HH}=$ Hip Height; $\mathrm{SnL}=$ Snout Length; HL=Head Length; IoD=Interorbital distance; EL=Ear Length; TL=Tailr Length; CP=Chest perimeter; $\mathrm{BL}=$ Body length; $\mathrm{LD}=$ Longtitudinal Diameter; $\mathrm{D} s \mathrm{D}=$ Dorsoestemal Diameter; $\mathrm{BD}=\mathrm{Bicostal}$ Diameter; $\mathrm{SL}=\mathrm{Shoulder}$ Length; HpL=Hip Length; IqQD=Interischiadic Distance. 
Table 8. Differences between coefficients of allometry (b) in relation of hip height in locally adapted Brazilian pig by breed

\begin{tabular}{|c|c|c|c|c|c|c|c|}
\hline \multicolumn{2}{|c|}{ Moura } & \multicolumn{2}{|c|}{ Piau } & \multicolumn{2}{|c|}{ Monteiro } & \multicolumn{2}{|c|}{ Nilo } \\
\hline Mean & SD & Mean & SD & Mean & SD & Mean & SD \\
\hline $0.48^{b}$ & 0.47 & $0.90^{\mathrm{ab}}$ & 0.79 & $0.61^{\mathrm{ab}}$ & 0.49 & $1.01^{\mathrm{a}}$ & 0.73 \\
\hline
\end{tabular}

$\mathrm{SD}-$ Standard deviation. Different letters $(\mathrm{a}, \mathrm{b})$ means significant difference by Tukey test $(5 \%)$

\section{Conclusions}

In general, the coefficients of allometry for both gender within a breed are of the same order, but differ between breeds. This difference in growth should be taken into account when developing management and conservation programs. Among the breeds used in this study, the Moura showed later developing traits linked to muscle growth (as chest perimeter) than to hip length. Monteiro pigs maintained many wild characteristics. The females showed body growth proportional to hip height. Males showed earlier body growth and development of longitudinal distance compared to hip height. These animals showed early growth.

\section{Acknowledgements}

The authors would like to thank CNPq and INCT-Pecuária (CNPq/MCT/FAPEMIG) for scholarships and $\mathrm{CNPq}$ Edital Prosul for financial resources.

\section{References}

1. McManus C, Paiva SR, Silva AVRS, Murata LS, Louvandini H, Cubilllos GPB, Castro GC, Martinez RA, Dellacasa MSL, Perez JE. 2010. Phenotypic characterization of naturalized swine breeds in Brazil, Uruguay and Colombia. Brazilian Archives of Biology and Technology, 53(3), 583-591.

2. Huxley JS. 1932. Problems of relative growth. London: Methuen; 1932, p.577.

3. Porter V, Alderson L, Hall SJG, Sponenburg DP. 2016. Mason's World Encyclopedia of Livestock Breeds and Breeding. Oxfordshire: CABI publishing, $1^{\text {st }}$ edition. 1107p.

4. Mariante AS, Albuquerque MSM, Egito AA, McManus C, Lopes MA, Paiva SR. 2009. Present status of the conservation of livestock genetic resources in Brazil. Livestock Science, 120: 204-212.

5.McManus C, Santos SA, Silva J, Louvandini H, Abreu UGP, Sereno JRB, Mariante AS. 2008. Body indices for the pantaneiro horse. Brazilian Journal of Veterinary Research and Animal Science, 45(5), 362-370.

6.Pacheco A, Quirino CR, Pinheiro OLVM, Almeida JVC. 2008. Medidas morfométricas de touros jovens e adultos da raça Guzerá. Revista Brasileira de Saúde e Produção Animal, 9(3), 426-435.

7.McManus C, Prescott E, Paludo GR, Bianchini E, Louvandini H, Mariante AS. 2009. Heat tolerance in naturalized Brazilian cattle breeds. Livestock Science, 120, 256-264.

8.Gusmão Filho JD, Teodoro SM, Chaves MA, Oliveira, SS. 2009. Análise fatorial de medidas morfométricas em ovinos tipo Santa Inês. Archivos de Zootecnia. 58, 289-292.

9.Landim AV, Mariante AS, McManus C, Gugel R, Paiva SR 2007. Características quantitativas da carcaça, medidas morfométricas e suas correlações em diferentes genótipos de ovinos. Ciência Animal Brasileira, 8 , 
$665-676$.

10.Evin A, Cucchi, T, Cardini, A, Vidarsdottir, US, Larson G, Dobney K. 2013. The long and winding road: identifying pig domestication through molar size and shape. Journal of Archaeological Science, 40, 735-743.

11.Costa Júnior GS, Campelo JEG, Azevedo DMMR, Filho RM, Cavalcante RR, Lopes JB, Oliveira ME. 2006. Caracterização morfométrica de ovinos da raça Santa Inês criados nas microrregiões de Teresina e Campo Maior, Piauí. Revista Brasileira de Zootecnia, 35, 2260-2267.

12.Santos CL, Pérez JRO, Geraseev LC, Muniz JA. 2001. Estudo do crescimento alométrico dos cortes de carcaça de cordeiros da raça Santa Inês e Bergamácia. Ciência e Agrotecnologia, 25(1), 149-158.

13. Mayhew, TM. 2006. Allometric studies on growth and development of the human placenta: growth of tissue compartments and diffusive conductances in relation to placental volume and fetal mass. Journal of Anatomy, 208(6): 785-794. http://doi.org/10.1111/j.1469-7580.2006.00566.x

14. Pacheco A, Quirino CR, Pinheiro OLVM, Almeida JVC. 2008. Medidas Morfométricas de Touros Jovens e Adultos da Raça Guzerá. Ver. Bras. Saúde Prod. An., v.9(3), 426-435.

15.Yáñez EA, Resende KT, Ferreira ACD, Medeiros AN, Sobrinho AGS, Filho JMP, Teixeira IAMA, Artoni SMB. 2004. Utilização de medidas biométricas para predizer características cabritos Saanen. Revista Brasileira de Zootecnia, 33(6), 1564-1572.

16.Bezerra SBL, Véras ASC, Silva DKA, Ferreira MA, Pereira KP, Santos GRA, Magalhães ALR, Almeida OC. 2012. Morphometry and carcass characteristics of goats submitted to grazing in the Caatinga. Revista Brasileira de Zootecnia, 41, 131-137.

17.Dobney K, Larson G. 2006. Genetics and animal domestication: new windows on an elusive process. Journal of Zoology, 269, 261-271.

18. Bright JA. 2012. The importance of craniofacial sutures in biomechanical finite element models of the domestic pig. Plos One, 7(2):e31769.

19. Sollero BP, Paiva SR, Faria DA, Guimarães SEF, Castro STR, Egito AA, Albuquerque MSM, Piovezan U, Bertani GR, Mariante A da S. (2009). Genetic Diversity of Brazilian Pig Breeds Evidenced by Microsatellite Markers. Livestock Science, 123: 8-15.

20. Li YX, Cabling MM, Kang HS, Kim TS, Yeom SC, Sohn YG, Kim SH, Nam KC, Seo KS. 2013. Comparison and Correlation Analysis of Different Swine Breeds Meat Quality. Asian-Australas J. Anim. Sci. 26(7): 905-910.

21. Lui JC, Baron J. 2011. Mechanisms Limiting Body Growth in Mammals. Endocr Rev. 32(3): 422-440.

22.Almeida MI. 2001. Avaliação do crescimento de tecidos e órgãos de novilhos mestiços Holandês-Gir durante o ganho compensatório, 1. Carcaça. Revista Brasileira Zootecnia, 30, 526-534.

23.Ávila VS, Osório JCS. 1996. Efeito do sistema de criação, época de nascimento e ano na velocidade de crescimento de cordeiros. Revista Brasileira Zootecnia, 25, 1007-1016.

24.Dutra Jr. WM, Ferreira AS, Donzele JL, Euclydes RF, Tarouco JU, Cardoso LL 2001. Predição de curvas de crescimento de tecidos de fêmeas suínas por intermédio da função alométrica estendida. Revista Brasileira de Zootecnia, 30(3), 1007-1014. 